\title{
The plays with the axe in armour of the Anonimo Bolognese (1510-1515)
}

\author{
Daniel Jaquet, \\ University of Geneva, \\ daniel.jaquet@unige.ch
}

\begin{abstract}
This contribution examines an anonymous text (Di Accia armato di tutt'arme) addressing the handling of the axe for armoured combat, compiled in a two-volume anonymous manuscript collection of the beginning of the $16^{\text {th }} \mathrm{c}$. This collection is of particular interest since it predates the "classical" authors of the Bolognese school of the $16^{\text {th }} \mathrm{c}$. and marks a turning point from an earlier late Medieval tradition. Moreover the inclusion of a text dedicated to armour fighting is equally interesting since this kind of combat tends to fade away from the technical register of the next Bolognese authors.

The manuscript is shortly described and the text is presented in a diplomatic edition, with a translation and a reproduction of the manuscript in appendices. The content is described and analysed from a technical and a historical point of view, allowing comparison with other similar treatises, identification of the arms and armour, and discussion of the context of application.
\end{abstract}

Keywords - Anonimo Bolognese, axe, chivalric game, armoured fencing, Historical European Martial Arts

Di Accia armato di tutt'arme (the axe armed with full harness) is exceptional for several reasons. First, the inclusion of such a text in the discourse of the anonymous compiler (Anonimo Bolognese), considered as one of the first authors of the Bolognese school of the $16^{\text {th }} \mathrm{c}$. whose writings have come to us, is surprising, because none of the following authors addresses this register anymore after him. Then, the text is a unicum, difficult to connect to any known tradition and its authorship is uncertain. It might be an original contribution of the compiler of the manuscript, or a text of an unknown origin compiled in the collection of the Anonimo Bolognese.

This source was brought to light in 2005 by Marco Rubboli and Luca Cesari, who offered a commented edition of the text and studies about the manuscript and interpretation of the fighting system ${ }^{1}$. This undated manuscript was never studied before, nor even described according to current scientific standard. It is only mentioned in the catalogue of the library in $1894^{2}$. The first volume contains an introduction (with principles, guards

\footnotetext{
1 Rubboli and Cesari, L'Arte della Spada.

2 "[Mss.] 345-6. Trattato della "gintilissima arte del schirmire", adesp. e acef. (Sec. XVI)" Bernicoli, Inventario dei manoscritti della Biblioteca Classense di Ravenna, p. 78. It can be traced to the library di San Vitale, deposed in the library Classense in 1811, but not earlier. There is a short note of Claudia
} 
and stepping), sword alone (spada sola), and sword alone against hafted weapon. The second volume contains sword in two hands, sword and combination (sword and small/large buckler, sword and targe, sword and rotella, sword and guanto da presa, sword and guanto da huomo d'arme), the axe in full harness, and the sword against mancino. The second volume is less organized than the first one, for the author addresses several registers in a miscellaneous order. This observation leads Rubboli and Cesari to consider the work as a personal collection, maybe a preparatory work, unachieved, for an intended printed book ${ }^{3}$.

This contribution focuses the analysis of Di Accia armato di tutt'arme. It discusses on the one hand its context of application and on the other hand its comparison with other similar treatises of the $15^{\text {th }}$ and $16^{\text {th }} \mathrm{c}$. In appendices are to be found a revised transcription and translation of the text, as well as a reproduction of the manuscript.

\section{IDENTIFYING THE CONTEXT}

\section{I.1. Arms and armour}

There is little doubt to the context of application of these plays. Although the source is not illustrated, the subtitle itself renders it quite clear: Di Accia armato di tutt'arme (the axe armed with full harness). The seventh play specifies that the thrust (punta) can be delivered "in the face or in whatever other part of his body that you find unarmed, such as the testicles..." (ferirlo di una punta ne la faccia, o in qualunque altra parte de la persona ti venesse destro, che non si trovasse armata, come ne li testicoli,...). Thus, the fighters were fully armed, probably with a head defense open or with a closed head defense, but with the visor open as was customary in chivalric games in the $15^{\text {th }} \mathrm{c}$. (see below).

The weapon is described as Accia (axe), composed of an aste (wooden shaft) on the lower end with a calcio or pedale (heel) that is reinforced with a spontone del calcio (metal point of the heel) used for thrusting action, and on the higher end with the metal head of the axe. The latter is composed of a corno (horn) - that is a spike named bec de faucon in old French -, a spontone (point) in the axis of the haft and a hammer (unmentioned in the text). This type of weapon is then similar to the one illustrated in the beginning of the 15 th $\mathrm{c}$. by

Giuliani (director of the library) about its provenience in the book of Cesari and Rubboli, L'Arte della Spada, p. 394. Besides its dimension, and a non-documented mention of a watermark, there is no published information nor scientific investigation of this manuscript available. This area is left for further studies. I thank Benedetto Gugliotta (Ufficio Manoscritti e Rari, Biblioteca Classense, Ravenna) for the provided information about the catalogue.

${ }^{3}$ Ibid. 
Fiore dei Liberi and in the last quarter of the century by Filippo Vadi in the relevant sections (Fig. 1) $)^{4}$.
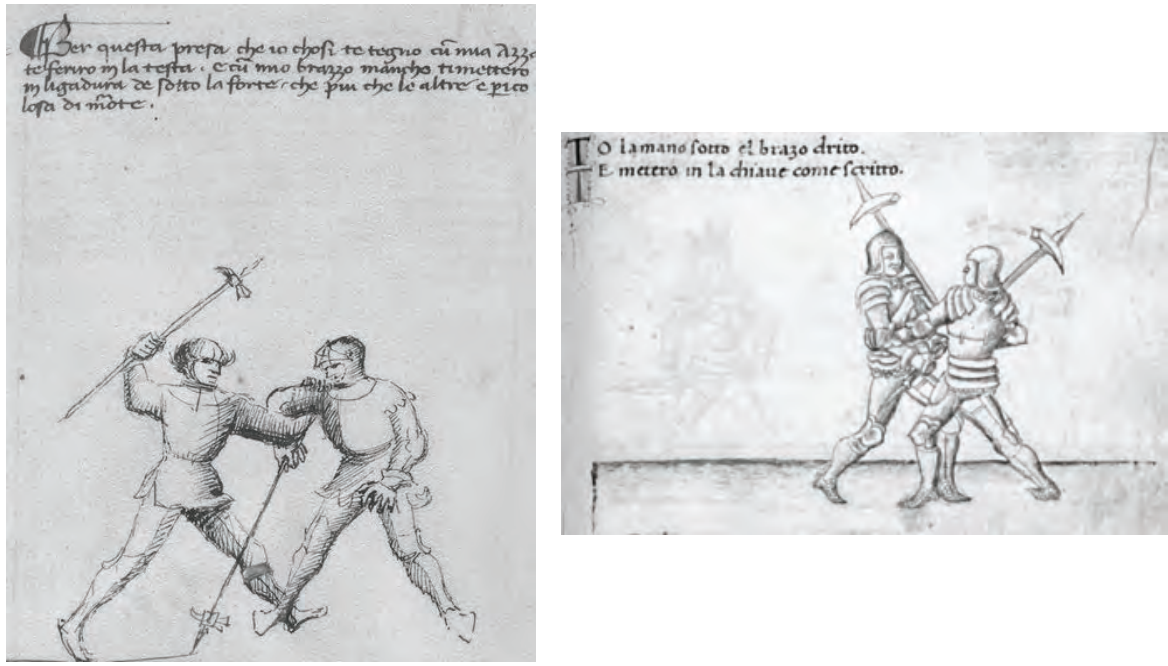

Fig. 1: Left panel: Fiore dei Liberi, Il Fior di Battaglia, 1410 (Los Angeles, Getty, ms Ludwig XV 13, fol. 37r, detail. Digital image courtesy of the Getty's Open Content Program). Right panel: Filippo Vadi, De Arte Gladiatoria Dimicandi, 1482-1487 (Roma, Biblioteca Nazionale, Ms Vitt. Em. 1324, fol. 25r, detail. Reproduced from ed. Mele/Porzio, p. 131).

\section{I.2. In a playful or in a more serious context?}

Fighting with an Accia (axe) in the fifteenth century was mainly related with chivalric games. These single confrontations were ruled by norms and usually understood as display of martial skills for knights in armour in a great variety of events commonly referred to as tournaments today, even if the term is actually misleading ${ }^{5}$. In other words, the related technical content of the fight books dealing with such type of fights is mostly inscribed in a playful context (mhg: schimpf, it. vulg.: per la cortesia), as opposed to a more

\footnotetext{
${ }^{4}$ Fiore dei Liberi, Flos Duellatorum, 1409 (ed. Rubboli/Cesari, pp. 201-212) and Filippo Vadi, De Arte Gladiatoria Dimicandi, 1485 (ed./transl Porzio/Mele, pp. 126-131 and ed. Rubboli/Cesari, pp. 100102). For a discussion of the type of axe (opposed to the views of S. Anglo) related to the anonymous Jeu de la Hache, see Raynaud, A la Hache, pp. 531-536.

${ }^{5}$ See the discussion of the secondary literature about this matter, put in the context of the Italian sources in the recent articles of Cavina, "La scienza dell'onore, il duello e la vendetta: Il disagio della trattatistica" and Cardini, "Il duello: alcune fonti e qualche problema". For the misuse of tournament, see ibid. p. 119 et seq.
} 
serious one (mhg: ernst, it. vulg.: per la vita) ${ }^{6}$. Nonetheless, specific plays are sometimes shown or described as being potentially deadly in a minority of cases in the $15^{\text {th }}-16^{\text {th }} \mathrm{c}$. fight books ${ }^{7}$.

The text compiled in the Anonimo Bolognese shows some insights allowing placing this text in the playful context. In the beginning of $\$ 4$, the author specifies a technique that would allow "hurting the opponent to the head", if "perchance" that was the intent (ma se per Aventura volendo tu ferire il tuo nemico a la testa), meaning that it was not the case by default. Similar comment is to be found in $\$ 7$, where the author details the thrust (punta) to be delivered if this is the last solution (cosi non ti dovrai mai rimanere). Finally, the play of $\S 9$ ends with an enlightening passage: “ $\ldots$ if you are wary with this art, and courageous, the enemy may do what he wants, and yet he will remain, against his will, conquered and taken prisoner". The use of the terms vinto (conquered) and pregione (taken prisoner) is indeed quite specific and - beyond the symbolic image - refer to technical terms for chivalric ethos in the context of chivalric games.

A careful analysis of the ending of the plays reveals that most of the techniques might end with a throw ( 9 plays, $60 \%$ of the content). Out of the 15 plays, 27 different outcomes are mentioned, as shown by Fig. 2 . One must note that the throw might be considered as a playful technique, since this outcome is usually ending the encounter in the context of a chivalric game, but also as a more serious one, since it could be followed up by a deadly technique. The same is true for the thrust, which might be considered as a deadly technique, whereas it is most of the time considered in the text as a technique actually leading to a throw (or a fall as a consequence) ${ }^{8}$. Indeed, the use of the heel or the spike of the axe is mainly used either to pull, push or "take" as shown in Fig. 2, but it can be used for more serious purpose as mentioned above (\$7).

\footnotetext{
${ }^{6}$ For a discussion of these context in the light of the judicial duel and the authors of the fight books, see Jaquet, “'Personne ne laisse volontiers son honneur être tranché.' Les combats singuliers 'judiciaires' d'après les livres de combat". For a discussion about Schimpf und Ernst in the context of German fencing practices, see Jaser, "Ernst und Schimpf - Fechten als Teil städtlicher Gewaltund Sportkultur" and for "giochi military", see Cardini, "Il duello: alcune fonti e qualche problema". ${ }^{7}$ Cfr. discussion about German sources below (section II).

${ }^{8}$ For example $\$ 8:$ “ $\ldots$ thrusting the point of your axe with great force into his belly, or into his groin upon the testicles, or in his throat, so that possibly, you will make him fall backward head over heels."
} 


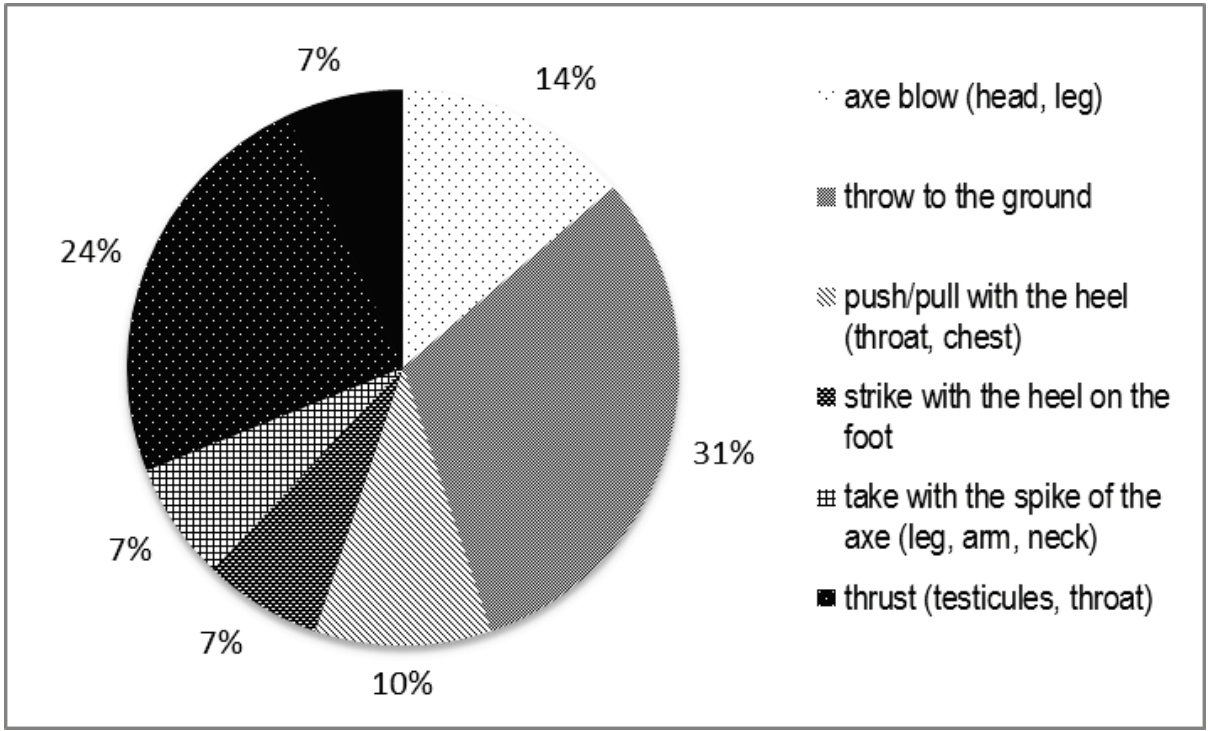

Figure 1: Ending of techniques (percentage of the number of occurrences). Author's diagram. Corresponding legend on the table below.

\begin{tabular}{|l|l|l|c|}
\hline \multicolumn{1}{|c|}{ Paragraph } & \multicolumn{1}{c|}{ Ending } & \multicolumn{1}{c|}{ Original text } & Occurrences \\
\hline $1,4,11,13$ & axe blow (head, leg) & acciata (testa, gambe) & 4 \\
\hline $\begin{array}{l}2,3,4,8,10, \\
11,12,13,14\end{array}$ & throw to the ground & tirarlo in terra / cadere in terra & 9 \\
\hline $4,9,10$ & $\begin{array}{l}\text { push/pull with the heel (chest, } \\
\text { throat) }\end{array}$ & $\begin{array}{l}\text { spingere il calcio de l'Accia nel } \\
\text { petto }\end{array}$ & 3 \\
\hline 5,15 & strike with the heel on the foot & col calcio ferirgli un piede & 2 \\
\hline 6,13 & $\begin{array}{l}\text { take with the spike of the axe } \\
\text { (leg, arm, neck) }\end{array}$ & $\begin{array}{l}\text { prendere col corno de l'accia } \\
\text { (gambe, braccia, collo) }\end{array}$ & 2 \\
\hline $\begin{array}{l}7,8,9,10,11, \\
12,14\end{array}$ & thrust (testicules, throat) & punta (testicoli, gola) & 7 \\
\hline 8,9 & disarm & levargliela di mano & 2 \\
\hline
\end{tabular}

\section{ANALYSING THE CONTENT AND COMPARING IT WITH OTHER FIGHT BOOKS}

Di Accia armato di tutt'arme is composed of 15 plays, without prologue or other paratext. The two stances are named guarda alta (high guard) and porta di ferro (iron door), the latter being specified as stretta (narrow) for 3 out of 4 mentions. The guarda alta is taken with the left foot forward and the axe held high over the right shoulder with the heel pointing towards the opponent $(\$ 1)$ and the porta di ferro is taken with the right foot forward and the axe held low towards the opponent $(\$ 2)$. The offensive actions are usually not described in details. The thrusts are referred to as punta. The blows are mostly referred to 
as acciata, and most of those are blows from above. Only once the author did specify a specific manner to deliver it referring to a common terminus technicus from the Bolognese tradition: "in the manner of a mandritto tondo" (\$13). Most of the other actions, disarming, pull or push in order to take, disarm or throw correspond to the ending of plays illustrated on fig. 2 .

The authorial hermeneutical choices of describing the plays are most of the time organized as a defensive action followed by a sequence of offensive actions, usually to the second or third intention. There are few counter-techniques mentioned in the plays, and the content is mostly organized as setups depending of different opposition between guards or specific defense against a specific offensive action. Basic actions of the system are described in $\$ 1-4$, going through the main opposition of guards. \$5-7 contain mostly principles and general advises to dominate the fight. \$8-14 develop specific techniques, following previous setups but going through alternative and more complex sequences. Finally $\$ 15$ is a feint.

There is little formal connection between the Accia armato di tutt'arme and the tradition of the play with the axe of the $15^{\text {th }} \mathrm{c}$. Italian authors. Fiore dei Liberi composed a section of 8 plays based on 6 stances followed by two tricks - including a recipe of a caustic powder to be hidden in the axe hammer'. Filippo Vadi compiled a shorter section of 4 plays based on 4 stances. The stances are not named alike and few of the technical content might be similar in some rare but not relevant cases (as for the Jeu de la Hache). Some of the termini technici can be traced in the discourse of Italian authors before and after the Anonimo Bolognese (such as the stance porta di ferro, or the offensive action such as punta or mandritto). Despite these very limited points of connection, there is no significant mark allowing us to postulate that this text is part of a previous tradition (faithful or unfaithful copy of text or image, similar technical content, order of presentation). Therefore this text is to be considered as a unicum (original that has no tradition) or part of an unknown tradition, which written or illustrated witnesses are lost or were never found. Di Accia armato di tutt'arme is one of such out of three, as pointed out by Terminiello ${ }^{10}$.

The closest fight book is technically the anonymous Jeu de la Hache, dated 1401-1500 by the $\mathrm{BnF}$, but probably written in the second half of the $15^{\text {th }} \mathrm{c}$. in a Burgundian area ${ }^{11}$. This is not surprising, since the duchy is famous for his champions of armoured combat with the axe (notably Jaques de Lalaing) and the dukes were fond of such chivalric games,

${ }_{9}^{9}$ Mondschein, The Knightly Art of battle, pp. 116, 122-123.

10 Terminiello, "Three Short Chapters from the Anonimo Bolognese". The two others are: Del modo da tenere nel combattere con la spada et col guanto da presa and Spada et guanto da huomo d'arme. See also the comments of Rubboli and Cesari, l'Arte della spada, p. 181, footnote 125 and p. 201, footnote 137.

11 See Dupuis/Deluz in this volume. See also Dupuis, "The French Fencing Traditions, from the 14th century to 1630 through Fight Books". For an analysis on le Jeu de la Hache, see Raynaud, A la bache!, pp. 496-592. 
turning Burgundy as one of the most famous place for such display of martial skills ${ }^{12}$. Moreover, there is at least one mention of an Italian master-at-arms, Ambroise de Milan, specialized on axe plays, paid by the duke Phillip the Good 12 livres to teach the young knights $^{13}$. This kind of exchange might point out a center of excellence for the play of the axe in armour in Northern Italy. Further research needs to be done, but I am confident that there are other sources documenting fencing praxes with the axe coming from Italy to Burgundy. The Jeu de la Hache is structured in 26 plays, divided by plays for right- and left-hander, based on two main stances - high and low, similar as those of the Anonimo Bolognese. Although there is no direct connection between the two, technical similarities with the Accia armato da tutt'arme are notably the context of application, the number and similarity of stances, the majority of the endings being throws, the feint with the feet as targets and at least 6 plays that are similar, although worded differently.

The aftermath of the Accia armato di tutt'arme is nowhere to be found, as for the Jeu de la Hache. The authors of the Bolognese school tended not to address anymore such type of combat in the course of the $16^{\text {th }} \mathrm{c}$. Instead, they address unarmoured combat with hafted weapons. Manciolino dedicated his sixth book of his work Opera Nova to the hafted weapons in 1531. He deals with unarmoured combat with partegiana (partisan), spiedo (spetum), ronca (bill), and lancia (spear). Similarly, Marozzo dedicated his the fourth book of his work Opera Nova to the hafted weapons in 1536. He deals indeed with unarmoured combat with partesana (partisan), spiedo (spetum) roncha (bill), and mentioned the acia (axe) as equivalent to alabarda (halberd) ${ }^{14}$. This echoes a principle formulated by Pietro Monte in his Collectanea published postmortem in 1509, but probably written in the last decades of the $15^{\text {th }}$ c.: "All staff weapons should be treated like the pollaxe, when we carry it low and with the heel extended forward. We should deliver the blows we use in the levada or in the initial teachings." 15 It is also noteworthy to underline that Pietro Monte is actually the first to compile teachings for the great variety of hafted weapons mentioned above, addressed by the later Bolognese authors.

This collusion between axe and halberd is already found in the dedicated section of the late $15^{\text {th }}$ c. fight book of the German master Peter Falkner, still placing such type of

\footnotetext{
12 See Priezel, "Schauspiele von Ehre und Tapferkeit. Zweikämpfe in Frankreich und Burgund im späten Mittelalter" and esp. Hiltmann, "Un État de noblesse et de chevalerie sans pareilles?: tournois et hérauts d'armes à la cour des ducs de Bourgogne”.

13 Archives Départementales du Nord, B 1972, fol. 198. Quoted in Sommé, "Les jeunes nobles à la cour de Bourgogne sous Philippe le Bon”, p. 82. This reference is cited by numerous authors, usually without reference.

14 Achille Marozzo, Opera nova, Cap. 185: Che tratta delle arme inastate contra a roncha, alabarda o acia.

15 Transl. from Forgeng, "Pietro Monte's Exercises and the Medieval Science of Arms", pp. 111112. Nota bene: the levata is a game explained in the first book of the Collectanea in the sword in two hands section, mainly composed of a sequence of two mounting blows. The author notes also the similarity between the plays with the sword in two-hands and the plays of the axe (triscuspidis).
} 
fighting in the context of "judicial" combat (kampff gericht) ${ }^{16}$. Several fight books from the German areas also contain a section dedicated to the armoured combat with the axe, however there is little connection with the Accia armato di tutt'arme on the technical point of view, nor from the context of application. It is interesting to note that, unlike on the Italian areas, the armoured fighting content is still compiled in the second half of the $16^{\text {th }}$ c. German fight books (such as in Paulus Hector Mair or in the manuscript version of the work of Joachim Meyer ${ }^{17}$ ). The content is then probably archaic for the readers and serves mainly as collection of authoritative texts. This function is eased by the manuscript medium and probably not ideal for the printed material. That may be one of the reason why the Bolognese authors of the $16^{\text {th }} \mathrm{c}$. did not include such content anymore in their printed work and may also explain why the Accia armato di tutt'arme is compiled in the anonymous collection of the Anonimo Bolognese.

\section{BIBLIOGRAPHY}

\section{III.1. Primary sources}

Achille Marozzo, Opera nova, Mutinae, D. Antonii Bergolae, 1536.

Anonimo Bolognese, s.t., ca. 1510-1515. Ravenna, Biblioteca comunale Classense, Mss Ravenna M-345/346 (cfr. ed. Rubboli and Cesari).

Anonymous, La Doctrine et l'industrie du noble jeu de la hache et la maniere de bataillier, 14011500 (ca. 1475). Paris, Bibliothèque Nationale Française, Ms fr. 1996.

Antonio Manciolino, Opera nova, Venezia, Nicolo d'Aristotile detto Zoppino, 1531.

Filippo Vadi, De arte gladiatoria dimicandi, 1482-1487 (cfr. ed. Rubboli and Cesari).

Fiore dei Liberi, Flos duellatorum, 1409 (cfr. ed. Rubboli and Cesari).

Peter Falkner, Kunste qu Ritterliche Were, ca. 1495 (cfr. ed. Tobler).

Pietro Monte, Exercitiorum atque artis militaris collectanea, Milano, Giovani Angelo

Scinzenzler, 1509.

\footnotetext{
16 Merck das ist auch ein leer wie du mit kemphlicher wer solt wartten mordt agst und hellebartten daß ist auch zu dem kampff gericht schleg stöß ringen macht zu nicht (Note this is also a lesson of how you should, with dueling weapons, act with the murder axe and the halberd, which is also for the judicial duel; striking, thrusting and wrestling counter-techniques). Tobler (ed. transl.), Master Peter Falkner's art of knightly defense, p. 274 et seq.

17 See for instance the text attributed to Hundsfeld, Lew and Lignitzer. For a discussion of their tradition, see Jaquet/Walczak, "Lignitzer, Hundsfeld or Lew? The question of autorship of popular Medieval fighting instructions".
} 


\section{III.2. Secondary literature and online resources}

Anonimo Bolognese, L'arte della spada: trattato di scherma degli inizi del XVI secolo, ed. by Marco Rubboli and Luca Cesari (Rimini: Il cerchio, 2005).

Cardini, Franco, "Il Duello: alcune fonti e qualche problema", in Agon und Distinktion. Soziale Räume des Zweikampfs zwischen Mittelalter und Neuzeit, ed. by Uwe Israel and Christian Jaser (Berlin: LIT Verlag, 2015), pp. 113-24.

Cavina, Marco, "La Scienza dell'onore, Il duello e la vendetta: Il disagio della trattatistica", in Agon und Distinktion. Soz̧ale Räume des Zweikampfs zwischen Mittelalter und Neuzeit, ed. by Uwe Israel and Christian Jaser (Berlin: LIT Verlag, 2015), pp. 101-12.

Dupuis, Olivier, "The French Fencing Traditions, from the 14th Century to 1630 through Fight Books", in Late Medieval and Early Modern Fight Books: Transmission and Tradition of Martial Arts in Europe (14th- to 17th-Centuries), ed. by Daniel Jaquet, Karin Verelst, and Timothy Dawson (Leiden: Brill, 2016).

Filippo Vadi, L'Arte Cavalleresca del Combattimento, ed. by Marco Rubboli and Luca Cesari (Rimini: Il Cerchio, 2005).

Fiore dei Liberi, Flos Duellatorum: Manuale di Arte del Combattimento del XV. secolo, ed. by Marco Rubboli and Luca Cesari (Rimini: Il Cerchio, 2002).

Forgeng, Jeffrey L., "Pietro Monte's Exercises and the Medieval Science of Arms", in The Armorer's Art. Essays in Honour of Stuart Pybrr, ed. by Donald J La Rocca (Woonsocket: Mowbray Publishing, 2014), pp. 107-14.

Hiltmann, Torsten, "Un État de Noblesse et de Chevalerie sans pareilles?: Tournois et Hérauts d'armes à la Cour des Ducs de Bourgogne', in La Cour de Bourgogne et l'Europe: Le rayonnement et les limites d'un modèle culturel, ed. by Werner Paravicini (Ostfildern: J. Thorbecke, 2013), pp. 253-88.

Jaquet, Daniel, “'Personne ne laisse volontiers son honneur être tranché.' Les combats singuliers 'judiciaires' d'après les livres de combat", in Armes et jeux militaires dans l'imaginaire (XIIe-XVe Siècles), ed. by Catalina Girbea (Paris: Classiques Garnier, 2016). Jaser, Christian, 'Ennst Und Schimpf - Fechten Als Teil Städtlicher Gewalt- Und Sportkultur', in Agon und Distinktion. Soziale Räume des Zweikampfs zwischen Mittelalter und Nenzeit, ed. by Uwe Israel and Christian Jaser (Berlin: LIT Verlag, 2015), pp. 221-42.

Pellet, Jon, "Pollaxe from the Anonymous Bolognese Source", self-published document, s.d.

Online, $<$ http://www.angelfire.com/planet/megalophias/anonimopollaxe.html> (accessed August 10, 2015).

Prietzel, Malte, "Schauspiele von Ehre und Tapferkeit. Zweikämpfe in Frankreich und Burgund im späten Mittelalter', in Das Duell - Ehrenkämpfe vom Mittelalter bis zur Moderne, ed. by Ulrike Ludwig, Barbara Krug-Richter, and Gerd Schwerhoff (Konstanz: UVK Verlagsgesellschaft, 2012), pp. 105-24. 
Raynaud, Christiane, 'A la Hache!': Histoire et symbolique de la hache dans la France médiévale (XIIIe-XVe siècles) (Paris: Le Léopard d’Or, 2002)

Sommé, Monique, "Les jeunes nobles à la cour de Bourgogne sous Philippe le Bon”, in Eræiehung und Bildung bei Hofe, ed. by Werner Paravicini (Stuttgart: Thorbecke, 2002).

Terminiello, Piermarco, "Three Short Chapters from the Anonimo Bolognese”, selfpublished document, s.d.

Online,

<http://schoolofthesword.com/Three $\% 20$ Short $\% 20$ Chapters $\% 20$ from $\% 20$ the $\% 20$ Anonimo\%20Bolognese.pdf> (accessed August 10, 2015).

Tobler, Christian, Captain of the Guild: Master Peter Falkner's Art of Knightly Defense (Wheaton:

Freelance Academy Press, 2010)

\section{APPENDIX 1. EDITION AND TRANSLATION}

\section{Norms}

This edition is a revised version of the transcription of Rubboli/Cesari, following the usual guidelines of diplomatic editions. The reader can refer to the reproduction of the manuscript in Appendix 2. The following editorial choices have been applied:

Punctuation: The punctuation of the original text is respected. The text is punctuated with regular point $<.>$ and comma $<,>$. No additional punctuation added in the edition.

Case: The upper and lower case of the original text is respected.

Original revisions: Erasure are signaled with the text crossed over (text). The in-line or superscript addition/correction are added in superscript.

Special signs and abbreviation: Abbreviation are resolved with the resolution underlined. Very few abbreviations in the original text, mainly $\langle\mathrm{p}\rangle$ (per) and the tilde. The $\langle\rho\rangle$ and $<\mathrm{S}\rangle$ are transcribed as $\langle\mathrm{S}\rangle$.

The translation is a revision of the translation of Jon Pellet. Termini technici are left in italic, followed by the translation (cf. glossary) in brackets. Translator notes or additions are added within straight brackets.

\section{Edition - translation}

\begin{tabular}{|l|l|}
\hline [24v] [§1] Trovandoti contra al tuo nemico con & 1. Finding yourself opposed to your enemy with \\
l'Accia in mano in guarda alta, col piede manco & axe in hand in guardia alta [high guard], with \\
innanzi, et con la man destra in alto levata, & the left foot forward, and with the right hand \\
trovandosi la sinistra innnanzi col calcio de & raised high, finding the left forward with the heel \\
l'Accia potrai passare col tuo destro piede & of the axe, you will be able to passare (pass) \\
innanzi, et mandargli uno mandritto a la testa, & forward with your right foot, and deliver a \\
provocando il nemico a schermirsene con & mandritto [right blow] to the head, provoking the \\
\hline
\end{tabular}


l'Accia, overo con l'asta, et così fatto vi verrete a trovare con l'aste de l'Accie incrociate inseme, onde tu starai aveduto, perciochè volendo passare il tuo nemico col suo piede manco innanzi, per percotere con il calcio de la sua Accia l'asta de la tua, per ferir poi col detto calcio il petto, o la faccia, potrai in quel tempo levare la tua Accia in alto, lasciando gire a voto il colpo suo, et subito mandargli una Acciata a la testa, et questo farai ciascuna volta, che tu ti trovassi con l'Accie incrociate, et chel nemico tuo si movesse a fare uno tale effetto col calcio de l'Accia sua.

[§2] Trovandoti con l'Accia in mano contra al tuo nemico col tuo piede manco innanzi in guardia alta, overo col destro in porta stretta di ferro, starai aveduto, percio che volendoti con alcun colpo offendere il tuo nemico la testa, passerai in quel tempo se sarai in porta di ferro, gran passo col tuo piede manco innanzi, alargando le braccia ben distese, sì che tu raccogli il suo colpo sopra l'asta de la tua Accia tra l'una et l'altra tua mano, volgendo subito con la manca il calcio de l'Accia tua sopra la sua testa et pigliatelo nel collo da la banda sinistra, ti procaccierai [25r] di tirarlo per il contrario a forza in terra, ma sij accorto, che nel tuo passare farà bisogno, che la tua gamba manca sia posta per fuori dal suo lato destro. enemy to defend himself with the axe, or with the haft, and that so done you will come to find yourselves with the hafts of the axes crossed together, whereby you will be attentive, so that your enemy wanting to passare (pass) forward with his left foot, to beat the haft of your axe with the heel of his, and then to wound your chest or face with the said heel, you will in that tempo [moment of time] lift your axe up high, letting his blow go by void, and suddenly deliver a acciata (blow) to his head, and this you will do every time that you have found yourself with axes crossed, and your enemy has moved to make such an effect with the heel of his axe.

2. Finding yourself with axe in hand opposed to your enemy with your left foot forward in guardia alta (high guard), or with the right in porta di ferro stretta (narrow iron door), you will pay attention, so that your enemy wanting to offend you with some blow to the head, if you are in porta di ferro (iron door), in that tempo (moment) you will take a large step forward with your left foot, speading your arms well outstretched, so that you receive his blow on the haft of your axe between your hands, suddenly turning the heel of your axe with the left [hand] over his head, and catching his neck on the left side, you will procure to pull him strongly backward to the ground, but be aware that in your passare (pass) it is necessary that your left leg is positioned to the outside of his right side.

[§3] Ma quando ti trovasti in guarda alta come è detto disopra, et volendio il tuo nemico offendere la testa tu passerai col tuo destro innanzi schermendo il colpo nel sopradetto modo, et così passerai con la manca gamba innanzi, facendo la medesma volta con il pedale de l'Accia tua, et con ogni destrezza et forza ti proccaccierai di farlo cadere in terra.

[§4] Ma se per aventura volendo tu ferire il tuo nemico a la testa, usase egli quello medesimo schivamento, per avolgerti poi il pedale de l'Accia sua atorno al tuo collo per farti cadere come è detto disopra, preponendo percio chel tuo colpo gli fosse mandato con la tua destra mano innanzi, potrai stare aveduto, percioche come egli forward, you will pay attention, so that as he
3. But when you find yourself in guardia alta (high guard) as said above, and your enemy wants to offend you in the head, you will step forward with your right [foot] fending off the blow in the manner above said, and so stepping forward with the left foot, making the same turn you will procure to make him fall to the ground

4. But if perchance you wanting to hurt your opponent in the head, he uses the same schivamento (defence), to turn at that time the heel of his axe about your neck to make you fall as said above; supposing therefore that your blow were delivered with the right hand with the heel of your axe, with all skill and force 
havra schermito il detto colpo tra l'una et l'altra sua mano come è detto, per volerti prendere col calcio nel collo, potrai tu in quel tempo abbandonando con la tua mano manca il pedale de l'Accia tua, et prender l'asta con la detta mano dal canto di l'Accia, et con il pedale dela tua calcio diessa potrai percotere il calcio de la nemica verso il suo destro lato, et così trovandosi di fuora, gli potrai poi spingere il calcio de l'Accia tua nel petto, overo se piu ti piacera prenderlo nel collo et mandarlo a terra, 0 pur vorrai ripigliare il pedale de la tua Accia con la mano manca, et dargli subito di una Acciata sopra la testa. defends the said blow between his hands as said, wanting to take you in the neck with the heel, you will be able in that tempo to release the foot of your axe with your left hand, take the haft with your said hand by the corner [junction of head and haft] of the axe, and with the heel of it you will be able to beat the enemy's heel toward his right side, and so finding him on your outside, you will be able to thrust the heel of your axe into his chest, or if you would prefer take him in the neck and send him to the ground, or if you like retake the foot of your axe with your left hand, and give him a sudden acciata (blow) on the head.

[\$5] Serai anchora aveduto, che trovandoti a 5 . You will moreover observe, that finding mezza Accia col tuo nemico gli potrai sempre col yourself at mezza accia (half-axe) with your calcio ferirgli un piede.

[25v] [§6] Serai anchora aveduto di atterrare il tuo nemico, ogni volta, che essendo seco a zuffa, ti venesse colto di poterlo prendere col corno de l'Accia in alcuna dele gambe, 0 dele braccia, 0 nel collo, 0 in alcuna altra parte dela persona.

[\$7] Così non ti dovrai mai rimanere, venendoti colto, di ferirlo di una punta ne la faccia, 0 in qualunque altra parte de la persona ti venesse destro, che non si trovasse armata, come ne li testicoli, o petenecchio, che dir ti piaccia.

[§8] Se tu ti ritrovassi contra il tuo nemico con il tuo piede destro innanzi, et con l'Accia posta in guisa di porta stretta di ferro, et egli contra di te ne la medesma guardia, et col piede destro ditto innanzi, potrai con il corno de la tua Accia prender la sua, et senza indugia dandogli con ogni tua forza una tratta verso te, farai opra di levargliela di mano, pur se colto non ti venisse, almeno seguira questo, che egli si proccacciera levarti la tua da la mani, come tu farai la sua, il che sucedendo, serai presto di passare in quel tempo col tuo piede destro innanzi, spingendogli con gran forza il spontone de l'Accia nel ventre, overo nel pettinicchio sopra li testicoli, o ne la gola, si che possendo, trabocando a l'indietro levi le gambe al cielo tu gli faci levare enemy you will always be able to wound him in the foot with the heel.

6. You will moreover be attentive to harass your enemy, at all times, that being in a quarrel with him, you could catch him with the corno (horn) of the axe in some part of the leg, or of the arm, or in the neck, or in some other part of his person.

7. So that you will never have to give in, you could hurt him with a punta (thrust) in the face, or in whatever other part his body is convenient, that you find unarmed, such as the testicles, or groin, as you please.

8. If you again found yourself opposed to your enemy with your right foot forward, and with the axe positioned in the manner of the porta di ferro stretto (narrow iron door), and him against you in the same guard, and with the right foot likewise forward, you will be able to catch his [axe] with the horn of your axe, and without delay giving him a pull toward you with all your force, you will try to remove it from his hand, yet if this doesn't succeed, at least this follows, that if he attempts to remove yours from your hands, as you will do his, you will be quick to step forward in that tempo (moment) with your right foot, thrusting the point of your axe with great force into his belly, or into his groin upon the testicles, or in his throat, so that possibly, you will make him fall backward 


\begin{tabular}{l}
\hline [§9] Ma se tu ti trovassi col tuo piede destro avanti \\
in guisa di porta stretta di ferro, et che lo nemico \\
tuo, ti spingesse del spontone de l'Accia, per ferirti \\
la gola, o il pettenicchio, o li piedi anteposti, potrai \\
far opra di prendere nel medesmo tempo [26r] con \\
il corno de l'Accia quella de lo nimico, dandogli una \\
grandissima tratta verso di te per cagione di \\
levargliela di mano, et forse non sera meraviglia, \\
levandogliela, con cio sia cosa, che in quello \\
tempo, che ti tirera il colpo, tu prendi l'Accia sua et \\
tiri non havendo egli in lei piu forza di quello, che \\
haver si pote, porto ferma credenza, che ti verra \\
colto il tuo pensiero, pur se non ti venisse, \\
successivamente scorrerai col tuo piede destro \\
alquanto innanzi dandogli del spontone con tutta la \\
forza tua nel pettenecchio sopra gli testicoli et nota, \\
che se con questa arte tu starai aveduto, et \\
animoso, faccia ciò che vole el nemico, et pur \\
rimara, mal suo grado, vinto et pregione.
\end{tabular}

[§10] Se ti trovassi agiato con il tuo piede manco innanzi, et in guisa di porta stretta di ferro similmente con la manca tua mano innanzi, et che 'I tuo nemico con il simile piede manco, et mano innanzi, ti mandasse una ferita de l'Accia sua al capo, potrai passare col tuo piede destro innanzi, schermendoti da cosi fatto colpo con il calcio de l'Accia tua, dandogli poi del spontone de la detta tua Accia ne la gola, overo vorai pigliarlo con l'asta del calcio ne la gola, con ogni tua forza verso le tue parti destre tirando talmente, che lo ponghi in terra, et molto meglio lo farai cadere se 'I tuo piede destro si troverà fuori dal suo sinistro.

[§11] Se tu trovasti il tuo nemico col suo manco piede innanzi, et con l'Accia in guisa di guardia alta, tu ti aconcerai, con I'Accia in guisa di porta di ferro stretta, et con il tuo piede destro innanzi [26v]et se quivi il tuo nemico scorresse avanti, per mandarti una Acciata al capo, tu subito passerai col tuo piede manco innanzi, schermendoti con l'asta del calcio, et fatto questo gli potrai subito spingere il spontone del calcio ne la gola, overo pigliandolo con l'asta del detto calcio ne la gola, head over heels.

9. But if you found yourself with your right foot forward in the manner of the porta di ferro stretta (narrow iron door), and that your enemy thrust at you with the spike of the axe, to hurt your throat, or groin, or foremost foot, you will be able in that same tempo to try taking with the horn of your axe that of your enemy, giving him a tremendous pull toward you in order to remove it from his hands, and maybe it will be no marvel, removing it from them, with this being so, that in that tempo (moment), that he will strike the blow at you, you take his axe and pull, he not having in it more force than this, that he could have, I firmly believe, that you will accomplish your intention, yet even it did not come to you, subsequently you will move your right foot somewhat forward giving him the point [of your axe] with all your force in the groin on the testicles and note, that if you are wary with this art, and courageous, the enemy may do what he wants, and yet he will remain, against his will, conquered and taken prisoner.

10. If you found yourself at settled with your left foot forward, and in the manner of the porta di ferro stretta (narrow iron door) likewise with your left hand forward, and that your enemy with the like left foot, and hand forward, delivered a blow of the axe to your head, you will be able to step forward with your right foot, and defend yourself from the blow so made with the heel of your axe, giving him afterward the spike of your said axe in the throat, or you will want to catch him with the haft of your axe in the throat, pulling him with all your force toward your right side, such that he is knocked to the ground, and you will make him fall much better if your right foot is found outside his left.

11. If you found your enemy with his left foot forward, and with the axe in the manner of the guardia alta (high guard), you will place yourself with your axe in the manner of the porta di ferro stretta (narrow iron door), and with your right foot forward and if there your enemy moved forward, to deliver a acciata (blow) to your head, you suddenly will step forward with your left foot, defending yourself with the haft of your heel, and this done you will be able to suddenly 
tirarlo sì verso le tue parti manche cha mal suo grado vada a terra.

[§12] Ti potrai anchora agiare in cotal modo contra al tuo nemico, cioè fare che il tuo piede manco sia innanzi, et la tua mano destra in alto appresso a l'Accia sendo la manca innanzi con il calcio, et in cotal modo cercherai stringere il nemico, facendo, che il tuo piede destro spinga il manco innanzi, con sembiante di dargli col spontone del calcio sopra il piede, et perché per questo sera astretto di accompagnare il calcio de la sua Accia con quello de la tua, li potrai levare l'Accia di mano in questa guisa, che mandandogli tu con grandissima forza uno colpo con l'Accia nel calcio della sua, sera sforzato egli senza fallo abbandonare l'Accia sua con la mano manca, perche successivamente potrai passare col tuo piede destro innanzi, rinovandogli uno colpo nel pettenicchio sopra i testicoli, col spontone de l'Accia tua, et con ogni forza in quel tempo con la detta tua Accia sollevarlo in suso, et spingendolo a l'indietro mandarlo a forza in terra

[§13] Sel tuo nemico si agiase [sic] con il suo piede manco innanzi, et con il calcio de l'Accia sua medesimamente innanzi, potrai tu agiarti col tuo piede destro innanzi, tenendo la manca tua [27r] mano al calcio, et la destra verso l'Accia, ma tanto alto quanto piu tu possi, et dandogli quivi a vedere di volerlo ferire con una Acciata sopra la testa, attenderai, che egli sollevi l'Accia sua in alcuna guisa per schermirsi, et in quel tempo serai tosto a mandargli una acciata in maniera di uno mandritto tondo per la gamba anteposta, et così gli leverai la gamba di sotto con il colpo, overo lo potrai pigliare col corno ne la detta gamba, tirandolo a forza sì che mal suo grado a terra giaccia thrust the point of the heel into his throat, or catching his throat with the haft of the said heel, to pull him toward your left side so that against his will he goes to the ground.

12. You will be able moreover to settle yourself in such a manner against your enemy, that is that your left foot be forward, and your right hand high near the axe [head], the left forward with the heel, and in such a manner you will seek to press your enemy, doing it so that your right foot pushes your left forward, with the semblance of giving him the point of the heel on the foot, and because of this he will be compelled to bring the heel of his axe to that of yours, so you will be able to remove the axe from his hand in this manner, that you delivering a blow of your axe with tremendous force on the heel of his, he will of force without fail release his axe with his left hand, so that subsequently you will be able to step forward with your right foot, redoubling with a blow in the groin on the testicles, with the point of your axe, and with all force in that tempo (moment) with your said axe raising him upward, and thrusting him backward, send him forcefully to the ground

13. If your enemy settles himself with his left foot forward, and with the heel of his axe forward in the same sort, you will be able to settle yourself with your right foot forward, holding the heel with your left hand, and the right toward the axe [head], but as high as you can, and there giving him the impression that you want to hurt him with a acciata (blow) on the head, you will observe, that he raises his axe in some manner to defend himself, and in that tempo (moment) you will be quick to deliver a acciata (blow) in the manner of a mandritto tondo [upward right blow] to his foremost leg, and so you will remove his leg from under him with the blow, or you will be able to catch the said leg with the horn [of your axe], pulling him forcefully so that against his will he will fall to the ground 
[§14] Ma se tu ritrovassi, et similemente il tuo nemico, col piede manco innanzi, et similemente con la medesma manca mano pur innanzi, potrai passare col tuo piede destro innanzi, mostrandogli di volergli dare d'una acciata sopra il capo, et come egli vorra schermirsene in alcuna guisa, subitamente raccogliendo I'Accia alquanto indietro, gli spingerai fortemente il spontone de l'Accia nel pettenecchio sopra li testicoli, o pur voi dire ne li testicoli, et dico tanto forte, che a l'indietro trabbocchi et vada in terra.

[§15] Trovandoti anchora tu, et tuo nemico col manco piede innanzi, et con la medes(i)ma mano pur innanzi, tu gli potrai mostare di volerlo ferire col spontone del calcio a la faccia, et in uno momento col detto spontone ferirgli il piede.
14. But if you found yourself the same as your enemy, with the left leg forward, and with the left hand forward likewise, you will be able to pass forward with your right foot, pretending to give a acciata (blow) on the head, and as he would defend himself in some way, at the same time collecting the axe somewhat backward, you will thrust the point of the axe strongly into this groin over the testicles, or if you want to say in the testicles, and I say very strongly, so that he falls backward to the ground

15. Once more finding yourself and your enemy with left foot forward, and with the same hand also forward, you will be able to pretend to strike him with the point of the heel to the face, and instantly strike him with the said point in the foot.

\section{Glossary}

\begin{tabular}{|l|l|}
\hline guardia alta & $\begin{array}{l}\text { High guard: Stance with left foot forward, the axe head over the right shoulder } \\
\text { and the axe butt in front. }\end{array}$ \\
\hline passare & To pass: stepping with the back foot over the front foot. \\
\hline mandritto & Right blow: downward blow delivered from the right handside \\
\hline acciata & Blow: cutting or chopping blow from the right or the left handside. \\
\hline tempo & Moment: time where a fencing action is performed. \\
\hline porta di ferro & $\begin{array}{l}\text { Iron door: Stance with left foot forward and left hand close to the body in front. } \\
\text { This stance can be narrowed (stretta). }\end{array}$ \\
\hline schivamento & defence: technical defensive action \\
\hline mezza accia & Half-axe: Situation when the two axes are bound by the shafts between hands. \\
\hline punta & Point: thrusting action \\
\hline
\end{tabular}




\section{APPENDIX 2. REPRODUCTION}

With kind permission of the Biblioteca comunale Classense of Ravenna.

Fol. 24v

\section{Di A cecia mante ditut'armb}

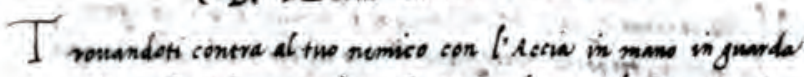

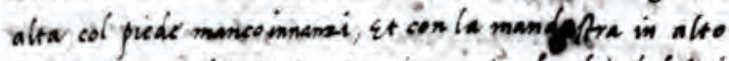

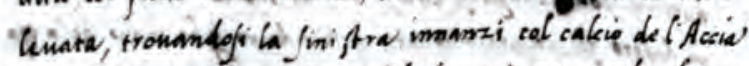

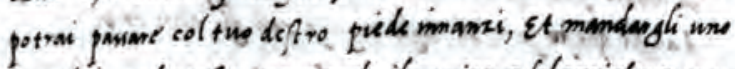

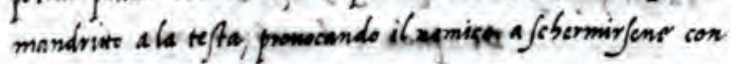

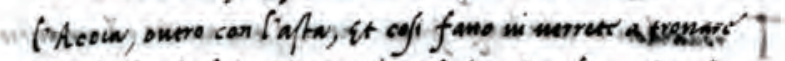

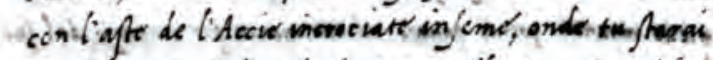

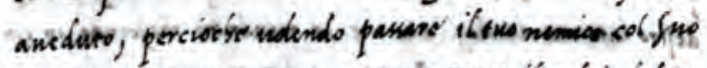

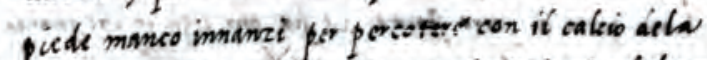

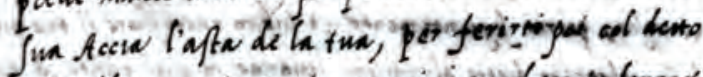

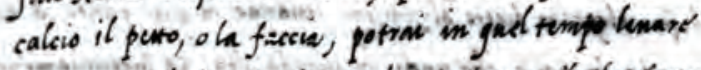

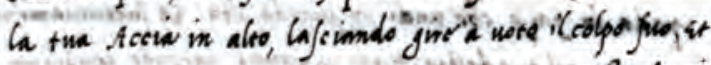

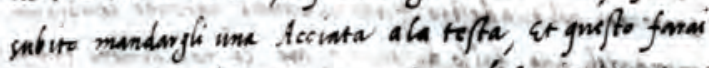

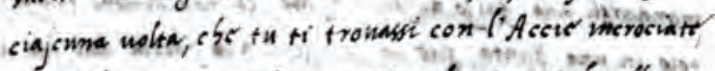

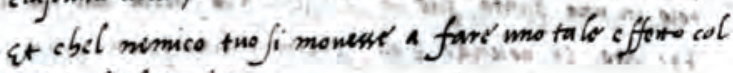
calorio de lis ceialsun.

Trouandotic con l'Acia mi mono contra al tuo némico vol mo piede manco mmanzi in guarda abra onero coldeftro in porta fruta di ferre, Jtarie anchure, percio che novendoti con alcum colpo offendere it the nemice la tefta, passermin guel tempo je ferne in porte di farre, grom pasio col tuo pride manco imonzi, alargando le braccia ben diftese, si che th raceggli il Jue colpo sopra ligfa de la tua Accia tra linma ct lialtra tua mano, nolgendo fúrvio cen la

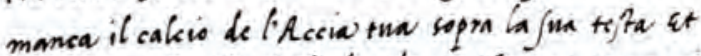
pugharelo nel coilo da la ónda siniftra, ti proconecierm 
fol. $25 \mathrm{r}$

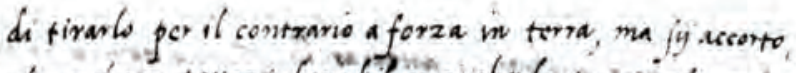

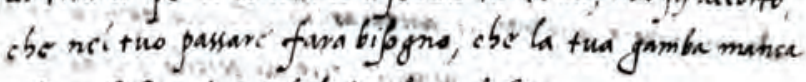
sia poftai of fuori dil juo tivo defreo.

M a guando nitrough inguarda alta comer deuro dijopia, it wo

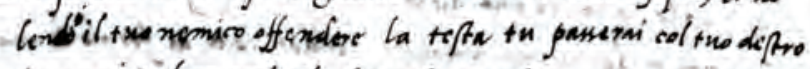

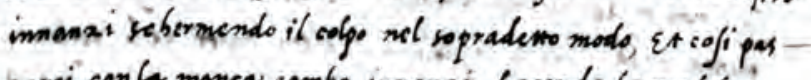

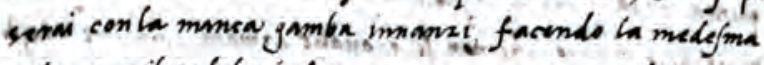

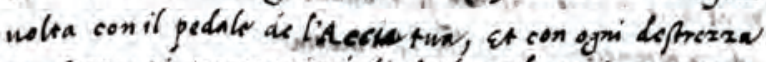
et forza ti procceaceverai di farlo cadere in torta." M a se perancontura notendo ta ferire il tno netmico a la

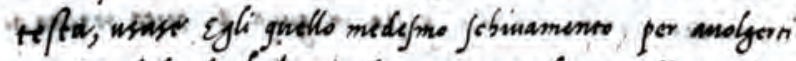
poi il pedale de li Alecia jua a torne al two colle pe furt

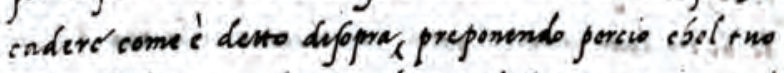
colpo gle fosse mandato con la twa deftra mmo momi,

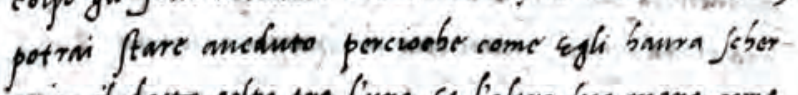

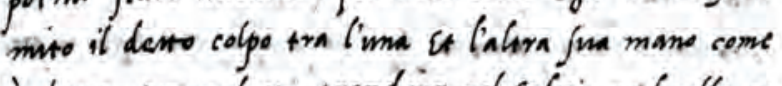
ideno, pex nokrti prendere col cakio nol collo, po

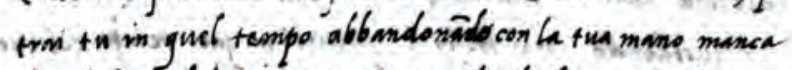
if pedale de l. A ceia twa, at primbo lagta cen la desita mamo dal conto di lificcia, et con il calesiqutiesta potrai per cotort if calcio dela nomica merfo if juo defrro lato, etcogi trouandofi difuora, gli potrni poi somgere if calcio de $/$ Accia. tha nel pento, onere pir ti piacera prenderlo net collo et mandarlo a terra, oper norrai ripighare it pedale dela

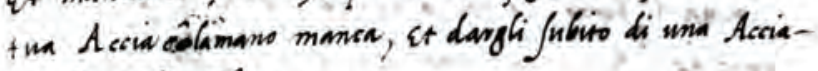
ta Jopre la tefar.

Serni mebora neduto che trouandoti a mexan Acrini col tho nomiso ofi potrm fempre col Calcio ferngli in piedo. 
fol. $25 \mathrm{v}$

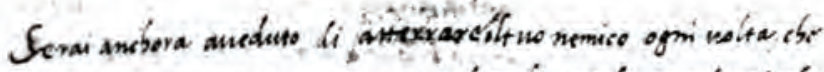

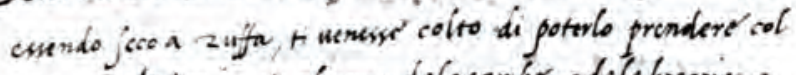
corno de l'Aecia in alsuna delejambe, odelebracsia. ni collo : malcuma altre parte dela perfoner.

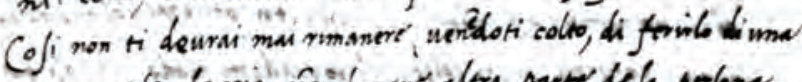

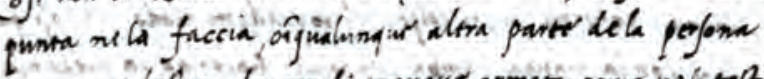

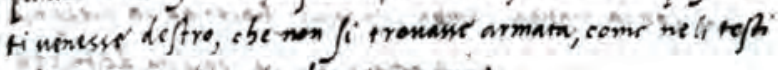

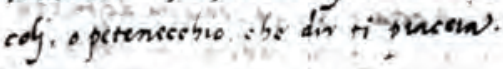

Ce th th titroussis conera if the nemico con if the piede defro

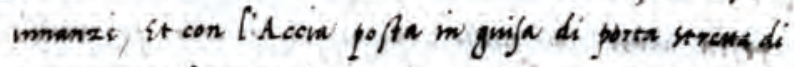

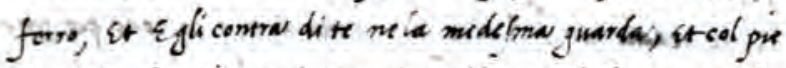

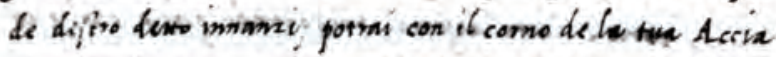
prendere la fun, et Jorza indugia dandogli con ogri tua forza

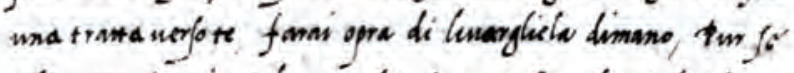
colto non ti usmise, almeno leguiro guefo, che eght is paes

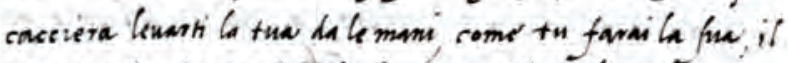
be Jusidends, serin fiffo di paseare in guel tempo col tho

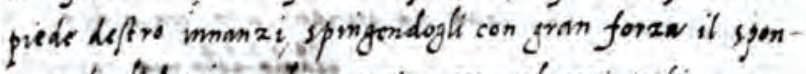
tons de PAccia met ventre onero nel penimesbio soora a li tefticoli, o mela gola, si che possende rabocennalo ilim

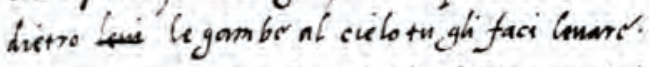

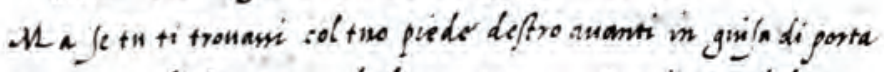
forta di forre, et che lo nemice twe, ti spingesse del spontone de l'Accia f ferirti la gola, o il pentenicebio, o liper di antepofi, potrni tar opra di prendere nel meds mo tompo 
fol. $26 r$

con if corne àc lit cria guilla de í mumice dondogh unagran -

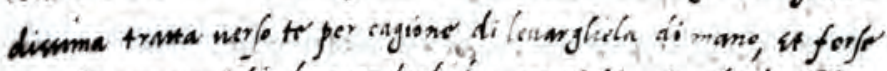

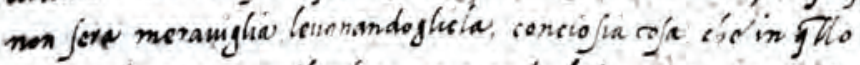
rempa, chertitirern if copo, th prende liscein fua it tivi

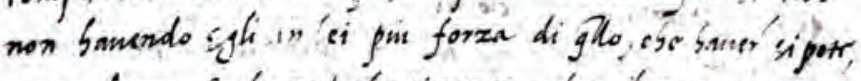
potto forma (acilenza), obsti nerra colro il tho pon ero,

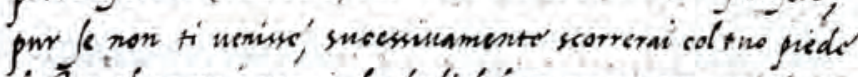
dc tro alguanto innonic andogli del spontone con turk la forzal

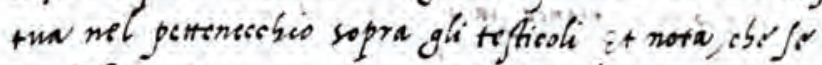
con Gfta arte th starai aneánto, et anmog. facein sio ct

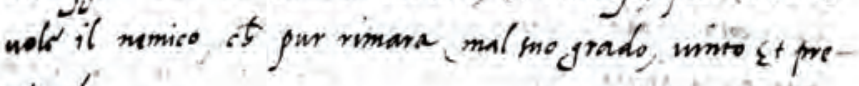
giond.

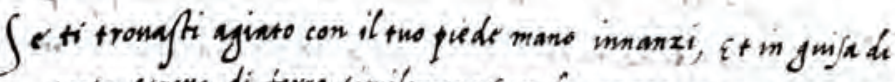
porta streuse di ferro similementricon la manea tua mane inna: Et chel tho nimico con it fimilr piedo mano, it mamo mnse ri mandases una ferita de l'Accia Ina al capo, potrai passar col tus puide dejtro manasi sebeomendoti de cofi frivo colpo con il calcio de l'Aceva tua domagli poi del spontone de la desta ina Accin melagola, onero norrm biglimb con liafa del calcie mela gola con ogri tua forza nelo le twe parti deftro triande talments ise lo ponghi in terva it molto meglis lo form cadere sel two piede deforo ri tronere difuora dal sno sinipro.

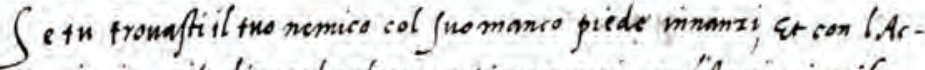

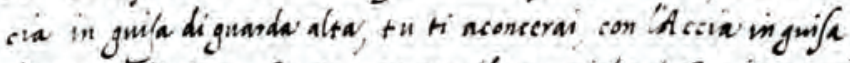

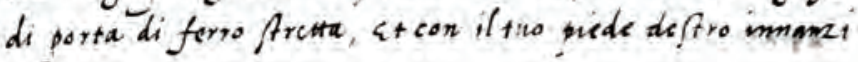


fol. $26 \mathrm{v}$

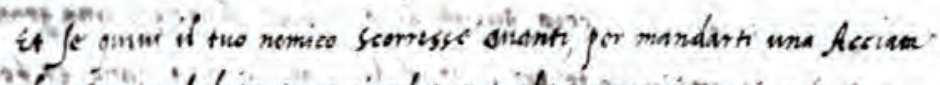

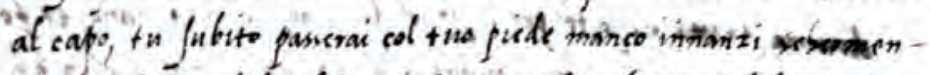

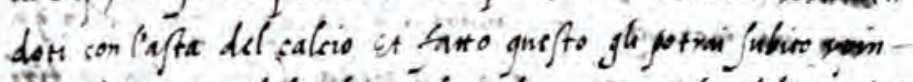

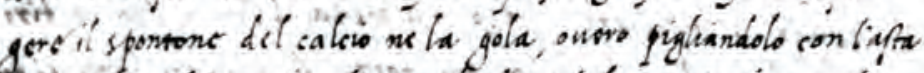

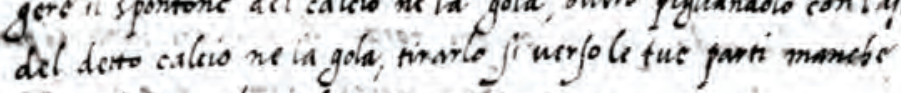
che malfinogrado indi a trrat?

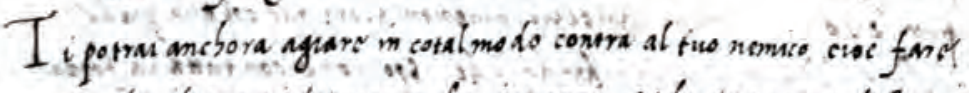
che il tho pude manco far mmanzi, et la tua mane dithe in

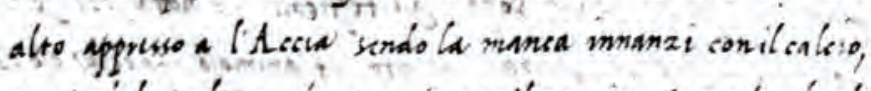
Et in cotal modo cereberm stringere it nemico facendo cos in? tho pude defho spinge il manco mmanzi con fombiante dider gli col spontone del caicio copra il pieds et perche jieguipo

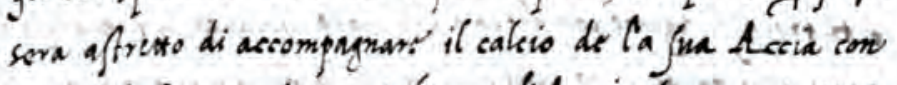
guche de la twa li potrmi lenare l $A_{\text {cria }}$ di mano in gripha

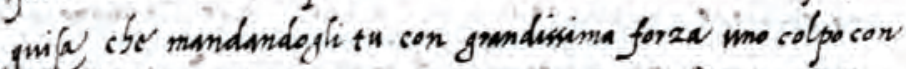

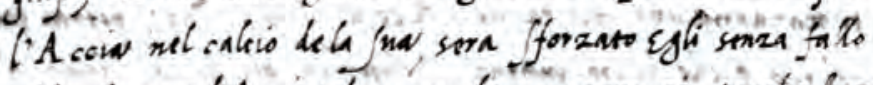

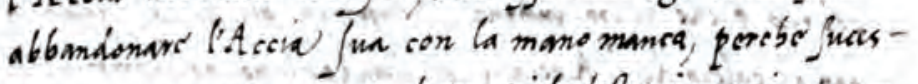
sismmentr potra passere col tho piele defro mmanis rino-

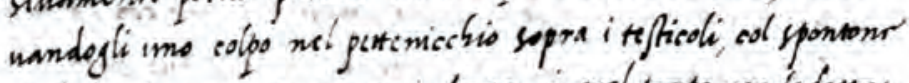
de l A ecia tua, $2+$ con ogmi forza in gurl tompo con ladena

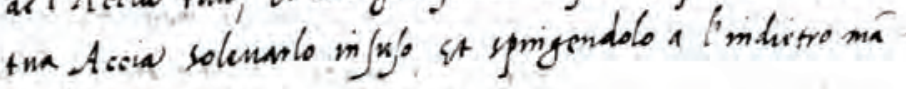
darb a wina forze in torra.

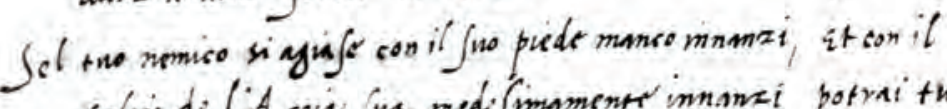
calow de l'A ccia fua medifmament imnanci potrait th agraiti col the puide deftro imanzi, tenendo la manca tua 
fol. $27 \mathrm{r}$

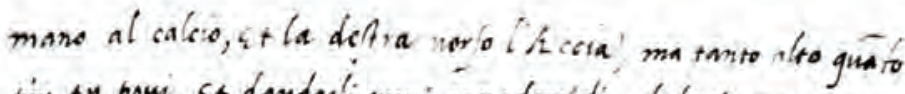

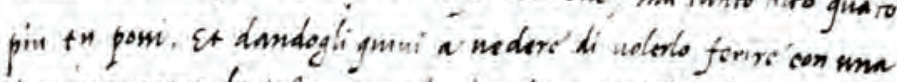

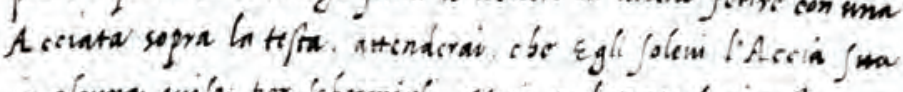

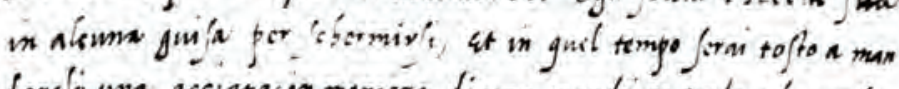

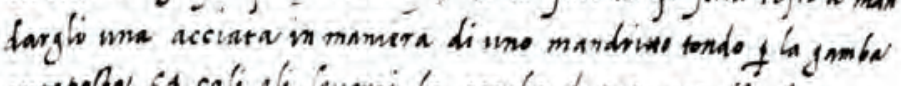

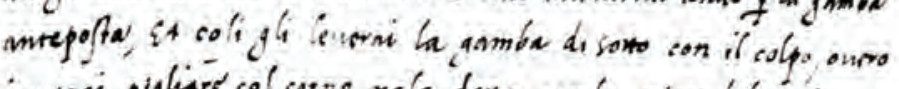

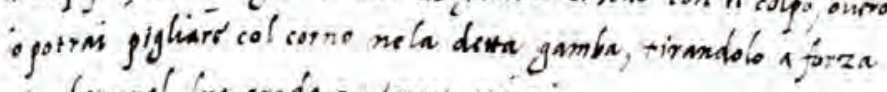

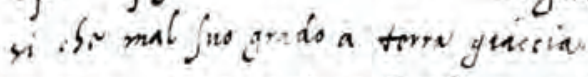

Ma a e th ti ritrounsis it imilementrif no nemico, nol puedr

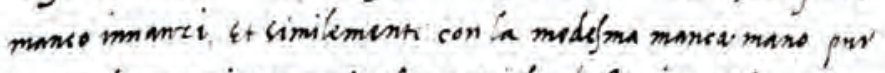

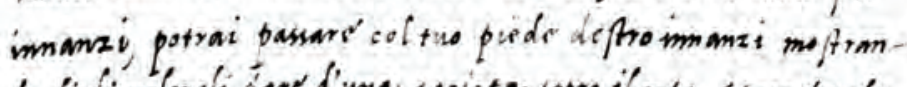

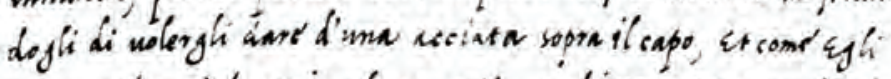

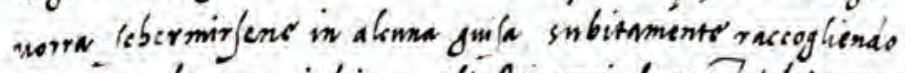

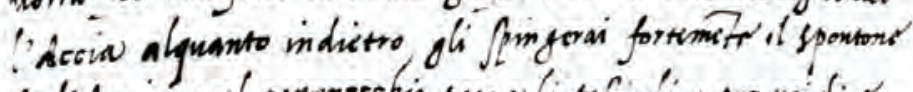

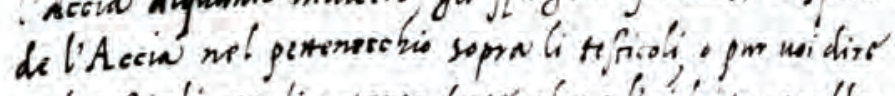

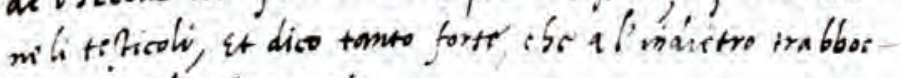
chi it uadi in sorral

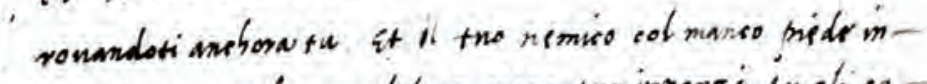
namet, itcon'a medalme mans pur immanzi ingligotrmi moltranc di nolerlo forrir col spontone del calsio a la fureia $c+i n$ mo mometo sol desto spontone ferightilpiat" 
